\title{
Suitable Groundwater Recharge Structures In Noyyal River Basin Coimbatore South Block Using Remote Sensing and GIS
}

\author{
Seemon Rayappa Raja ${ }^{1}$, Karibasappa ${ }^{2}$ \\ ${ }^{1}$ P.G. Student, Department of Civil Engineering, Adhiyamaan College of Engineering, Hosur, India \\ ${ }^{2}$ Professor, Department of Civil Engineering, Adhiyamaan College of Engineering, Hosur, India
}

\begin{abstract}
Land and water resources are limited and their wide utilization is imperative, especially for countries like India, due to increase in the population. Any economic activity like agriculture, industries or domestic activities are highly dependent on the water resource. Water is an important resource that needs to be conserved for sustainable development. Management and conservation of water is the need of the day. Water resource development programs are applied generally on watershed basis and thus prioritization is essential for proper planning and management of water resources for sustainable development. In this study made to analyse morphometric parameters of six sub watershed of Noyyal river basin in Coimbatore south block, Coimbatore district Tamilnadu. The main objective of the study is to identify the suitable site and structures for the groundwater recharge. The morphometric parameters like stream ordering, stream length, stream length ratio, and bifurcation ratio, drainage density, stream frequency, form factor, circulatory ratio, and elongated ratio were analyzed to know the characters of the watershed. The suitable site was identified by the integration of the various thematic maps like land use/land cover map, geomorphological map, geology map, slope map, soil map, drainage density map, lineament map based on the weightage for the different features. The suitable structure for groundwater recharge was identified by the integration of thematic map and also by field visit.
\end{abstract}

Keywords: Morphometric, Watershed, Land use/land cover map, Soil map, Thematic map

\section{Introduction}

The study of the river basin Morphometric analysis provides the useful parameter for the assessment of the groundwater potential, surface and groundwater resource management, runoff and geographic characteristics of the drainage system. Morphometric is the measurement and mathematical analysis of the configuration of the earth's surface, shape, dimension of its landforms. The Morphometric analysis includes the linear aspects and aerial aspects, in the linear aspects the stream ordering, stream length, stream length ratio, and bifurcation ratio and in the aerial aspect the drainage density, stream frequency, form factor, circulatory ratio, and elongated ratio has been calculated.

\section{Study Area}

The study area of the watershed is the Noyyal river basin is $180 \mathrm{~km}(110 \mathrm{mi})$ long and $25 \mathrm{~km}$ (16 mi) wide and covers a total area of $3,500 \mathrm{~km}^{2}$ (1, $400 \mathrm{sq}$. mi) lies between the latitude $12.55-12.35 \mathrm{~N}$ and longitude of 77.45-78.00 $\mathrm{E}$ in Coimbatore South block of Coimbatore district, Tamilnadu state. Coimbatore South Block is a town and a municipality in Coimbatore district in the Indian State of Tamilnadu

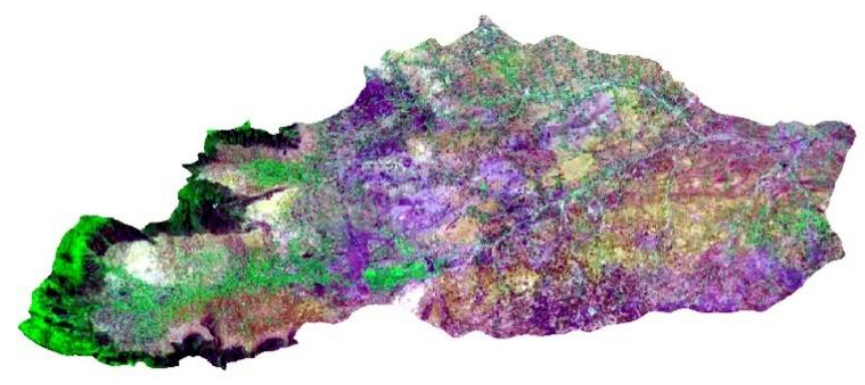

Figure 1: Study Area Map

\section{Materials and Methodology}

In the present study morphometric analysis and prioritization of watershed was carried out based on the integration of the remote sensing and GIS technique. The satellite data used for the study is IRS P6 (LISS IV) which was collected from the National Remote Sensing Centre (NRSC) Hyderabad. The Toposheets used for the study are $54 \mathrm{H} / 13$ and $54 \mathrm{H} / 14$ of 1:50000 scale obtained from the Tamilnadu State Capital Survey of India (SOI), Chennai. The delineation of the watershed is done using the software an Arc map 10. The drainage features of the watershed were digitized manually using the arc GIS software. The ordering of the drainage were done in reference to the staler. The morphometric parameters were calculated manually. The ranking of the parameters were given in the increasing order. The prioritizations of the watershed were obtained from the average of the ranking of various parameters. The features of the various thematic maps were given weightage according to the water recharge potential. Figure 2 show the flowchart represents the methodology. 


\section{International Journal of Science and Research (IJSR) \\ ISSN (Online): 2319-7064}

Index Copernicus Value (2013): 6.14 | Impact Factor (2014): 5.611

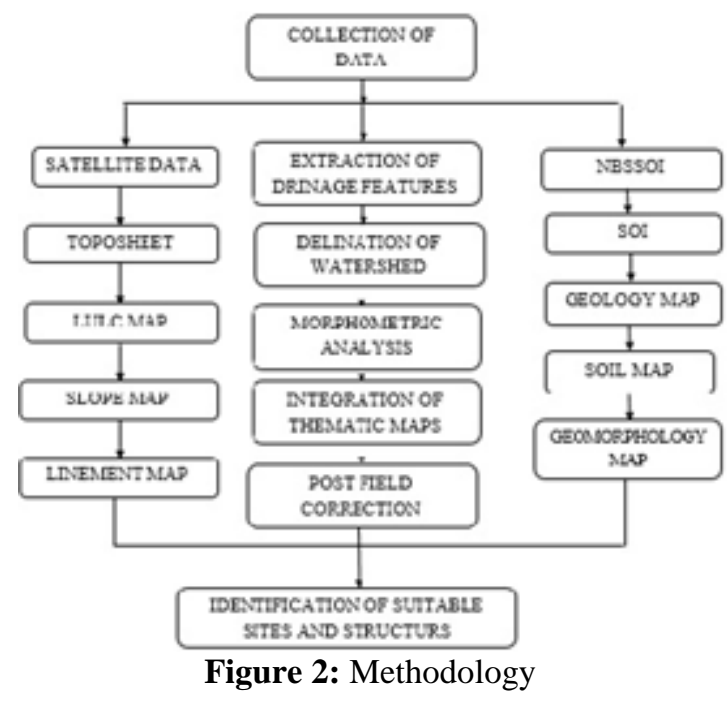

\section{Morphometric Parameters}

Morphometry is defined as the measurement and mathematical analysis of the configuration of the earth's surface and of the shape and dimension of its landforms (Clarke, 1966).The Main purpose of this work has to discover holistic Stream Properties from measurement of various attributes. A major emphasis in geomorphology over the past several decades has been on the development of quantitative physiographic methods to describe the evolution and behavior of surface drainage networks (Horton-1945; Leopold \& Maddock-1953; Abrahams-1984). Most previous morphometric analyses were based on arbitrary areas or individual channel segments. Using watershed as a basic unit in morphometric analysis is the most logical choice. A watershed is the surface area drained by a part or the totality of one or several given water courses and can be taken as a basic erosional landscape element where land and water resources interact in a perceptible manner. In fact, they are the fundamental units of the fluvial landscape and a great amount of research has focused on their geometric characteristics, including the topology of the stream networks and quantitative description of drainage texture, pattern and shape (Abrahams, 1984). The morphometric characteristics at the watershed scale may contain important information regarding its formation and development because all hydrologic and geomorphic processes occur within the Watershed (Singh 1992). The morphometric parameter with formulae is shown in Table 1.

1. The quantitative analysis of morphometric parameters is found to be of immense utility in river basin evaluation, watershed prioritization for soil and water conservation and natural resources management at watershed level. Morphometric analysis of a watershed provides a quantitative description of the drainage system which is an important aspect of the characterization of watersheds (Strahler, 1964). The influence of drainage Morphometry is very significant in understanding the landform processes, soil physical properties and erosional characteristics. Drainage characteristics of many river basins and sub basins in different parts of the globe have been studied using conventional methods (Horton, 1945; Strahler, 1957, 1964; Krishnamurthy et al., 1996). Geographical Information
System (GIS) techniques are now a day used for assessing various terrain and morphometric parameters of the drainage basins and watersheds, as they provide a flexible environment and a powerful tool for the manipulation and analysis of spatial information.

Table 1: Morphometric parameters

\begin{tabular}{|c|c|c|}
\hline $\begin{array}{c}\text { Morphometric } \\
\text { Parameters }\end{array}$ & Method & Reference \\
\hline Stream order & Hierarchial rank & Strahler(1964) \\
\hline $\begin{array}{c}\text { Stream } \\
\text { length }(\mathrm{Lu})\end{array}$ & Length of the stream & Hortan(1945) \\
\hline $\begin{array}{l}\text { Mean stream } \\
\text { length (Lsm) }\end{array}$ & $\begin{array}{c}\text { Lsm }=\mathrm{Lu} / \mathrm{Nu} \\
\text { Where } \mathrm{Lu}=\text { total stream } \\
\text { length of order , ,ü, } \mathrm{Nu}=\text { total } \\
\text { number of stream segments of } \\
\text { order ,, } \mathrm{u}^{\text {ee }}\end{array}$ & Strahler (1964) \\
\hline $\begin{array}{l}\text { Stream length } \\
\text { ratio (RL) }\end{array}$ & $\begin{array}{c}\mathrm{RL}=\mathrm{Lu} / \mathrm{Lu}-1 \\
\text { where } \mathrm{Lu}=\text { Total stream } \\
\text { length of order , ,ue, } \mathrm{Lu}-1= \\
\text { The total stream length of its } \\
\text { next lower order }\end{array}$ & Horton (1945) \\
\hline $\begin{array}{l}\text { Bifurcation ratio } \\
\text { (Rb) }\end{array}$ & $\begin{array}{c}\mathrm{Rb}=\mathrm{Nu} / \mathrm{Nu}+1 \\
\text { where } \mathrm{Nu}=\text { Total no. of } \\
\text { stream segments of order , ,ue, } \\
\mathrm{Nu}+1=\text { Number of segments } \\
\text { of the next higher order }\end{array}$ & $\begin{array}{l}\text { Schumm } \\
\text { (1956) }\end{array}$ \\
\hline $\begin{array}{l}\text { Drainage density } \\
\text { (Dd) }\end{array}$ & $\begin{array}{c}\mathrm{Dd}=\mathrm{Lu} / \mathrm{A} \\
\text { where } \mathrm{Dd}=\text { drainage density, } \\
\mathrm{Lu}=\text { total stream length of all } \\
\text { orders, } \mathrm{A}=\text { area of the } \\
\text { basin }\left(\mathrm{km}^{2}\right)\end{array}$ & Horton (1945) \\
\hline $\begin{array}{c}\text { Stream } \\
\text { frequency (Fs) }\end{array}$ & $\begin{array}{c}\mathrm{Fs}=\mathrm{Nu} / \mathrm{A} \\
\text { where } \mathrm{Fs}=\text { stream frequency, } \\
\mathrm{Nu}=\text { total number of streams } \\
\text { of streams of all orders, } \mathrm{A}= \\
\text { area of the basin, } \mathrm{km}^{2}\end{array}$ & Horton (1945) \\
\hline $\begin{array}{l}\text { Circulatory } \\
\text { ratio(Rc) }\end{array}$ & $\begin{array}{c}\mathrm{Rc}=4 * \pi * \mathrm{~A} / \mathrm{P}^{2} \\
\text { where } \mathrm{Rc}=\text { circularity ratio, } \pi \\
=\pi \text { value i.e., } 3.141, \mathrm{~A}=\text { area } \\
\text { of the basin, } \mathrm{km} 2, \mathrm{P}^{2}=\text { square } \\
\text { of the perimeter, } \mathrm{km}\end{array}$ & Miller (1953) \\
\hline $\begin{array}{l}\text { Elongation ratio } \\
\text { (Re) }\end{array}$ & $\begin{array}{c}\mathrm{Re}=\left(4^{*} \mathrm{~A} / \pi\right) 0.5 / \mathrm{Lb} \\
\text { where } \mathrm{Re}=\text { elongation ratio, } \\
\mathrm{A}=\text { area of the basin, } \mathrm{km}^{2} \text {, } \\
\pi=\pi \text { value i.e., } 3.141, \mathrm{Lb}= \\
\text { basin length, } \mathrm{m}\end{array}$ & Miller (1953) \\
\hline Form factor (Ff) & $\begin{array}{c}\mathrm{Ff}=\mathrm{A} / \mathrm{Lb}^{2} \\
\text { where, } \mathrm{Ff}=\text { form factor, } \mathrm{A}= \\
\text { area of the basin, } \mathrm{km}^{2}, \mathrm{Lb}= \\
\text { basin length }\end{array}$ & $\begin{array}{l}\text { Schumm } \\
\text { (1956) }\end{array}$ \\
\hline $\begin{array}{l}\text { Drainage texture } \\
\text { (Rt) }\end{array}$ & $\begin{array}{c}\mathrm{Rt}=\mathrm{Nu} / \mathrm{P} \\
\text { where } \mathrm{Nu}=\text { total no. of } \\
\text { streams of all orders, } \mathrm{P}= \\
\text { basin } \\
\text { perimeter, } \mathrm{km}\end{array}$ & Horton (1945) \\
\hline $\begin{array}{l}\text { Compactness } \\
\text { constant } \\
\text { (Cc }\end{array}$ & $\begin{array}{c}\mathrm{Cc}=0.2821 \mathrm{P} / \mathrm{A} 0.5 \\
\text { Where Cc = Compactness } \\
\text { Ratio, A = Area of the basin, } \\
\mathrm{km}^{2}, \mathrm{P}=\text { basin perimeter, } \mathrm{km}\end{array}$ & Horton (1945) \\
\hline $\begin{array}{l}\text { Length of over } \\
\text { land flow (Lo) }\end{array}$ & $\begin{array}{c}\mathrm{Lo}=1 / 2 \mathrm{Dd} \text { where } \mathrm{Lo}=\text { length } \\
\text { of overland flow, } \mathrm{Dd}= \\
\text { drainage density }\end{array}$ & Horton (1945) \\
\hline $\begin{array}{l}\text { Shape factor } \\
\text { (Bs) }\end{array}$ & $\begin{array}{l}\mathrm{Bs}=\mathrm{Lb}^{2} / \mathrm{a} \text { where } \mathrm{Bs}=\text { shape } \\
\text { factor, } \mathrm{Lb}=\text { basin length, } \mathrm{A}= \\
\text { area of the basin }\left(\mathrm{km}^{2}\right)\end{array}$ & $\begin{array}{l}\text { Nookratnam et } \\
\text { al(2005) }\end{array}$ \\
\hline
\end{tabular}




\section{International Journal of Science and Research (IJSR) \\ ISSN (Online): 2319-7064}

Index Copernicus Value (2013): 6.14 | Impact Factor (2014): 5.611

\section{Results and Discussion}

The morphometric parameters for the six watersheds were carried out in the study. The morphometric parameters are of linear parameters and shape parameters. The Drainage order map is shown in Figure 3. The morphometric parameters are shown in Table 2.

\section{Linear Parameters}

The linear morphometric parameters are bifurcation ratio, drainage density, stream frequency, drainage texture, length of overland flow.

\section{Bifurcation Ratio (Rb)}

It is the ratio of number of streams of a given order to the number of streams of the next higher order (Schumm, 1956). The ratio varies with the different classifications of stream orders. The lower values of 'Rb' are characteristics of the sub-watersheds which have less structural disturbances (Strahler, 1964) and the drainage pattern has not been distorted due to the structural disturbances. In present study the bifurcation value ranges from 3-7.5. The Rb-values of the sub watershed in the study indicates that the SW1 is highly structural disturbed and other sub watershed is less structurally disturbed.

\section{Drainage Density (Dd)}

The estimation of drainage density is a useful numerical measure of landscape dissection and runoff potential (Chorley, 1962). On the one hand, the drainage density is a result of interacting factors controlling the surface runoff. But on the other hand, it is influencing the output of water and sediment from a drainage basin. Drainage density expresses the closeness of spacing of channels. The lower values of , $\mathrm{Dd}^{\text {ee }}$ leads to course drainage texture and a higher value for fine texture (Strahler, 1964). In the present study the drainage density ranges from $1.22 \mathrm{~km} / \mathrm{km}^{2}$. In the study SW1 and SW2 had medium drainage density and SW3, SW4, SW5 and SW6 has higher drainage density which indicates they are fine textured, impermeable sub surface material and poor vegetation.

\section{Stream Frequency (Fs)}

Stream frequency/channel frequency (Fs) is the total number of stream segments of all orders per unit area(Horton, 1932). The low values of 'Fs' indicate that the area is of low relief with permeable subsurface material. In the study the Fs ranges from 1.66 to 2.72 . The dense forest has low stream frequency and the high agriculture land have more runoff and high stream frequency. The SW2 have high stream frequency of 2.72 and the SW1 have low stream frequency of 1.66. The number of streams increase with respect to increase in drainage density.

\section{Texture Ratio (Rt)}

Texture ratio is an expression of the relative channel spacing in fluvial dissected terrain. It depends on a number of natural factors such as climate, rainfall, vegetation, rock and soil type, infiltration capacity, relief and stage of development of a basin (Smith, 1950). Horton recognized infiltration capacity as the single important factor which influences drainage texture (Rt) and considered the drainage texture to include drainage density and stream frequency. Smith (1950) has classified drainage density into five different texture i.e., very coarse $(<2)$, Coarse $(2-4)$, moderate $(4-6)$, fine (6- 8) and very fine $(>8)$. In the present study area the 'Rt' value range from 1.96 to 7.64 indicating that SW4 is fine textured and SW1, SW2, SW3.SW5.SW6 are coarse textured.

\section{Length of Overland Flow (Lo)}

Length of overland flow is one of the most important independent variables affecting both the hydrologic and physiographic development of drainage basin. It is the length of water over the ground before it gets concentrated into definite stream channel. It is approximately equal to one half the reciprocal of the drainage density. In the present study the length of overland flow varies from 0.24 to 0.39 . Generally higher value of Lo is indicative of low relief and whereas low value of Lo is an indicative of high relief.

\section{Shape Parameters}

The shape parameters of the morphometric parameters are form factor, circularity ratio, elongation ratio, shape factor, compactness coefficient.

\section{Form Factor (Rf)}

The form factor ,Rfe points out the shape or outline form of a drainage basin capable of being understood and affects stream discharge behaviors. The ratio of the basin area to the square of basin length is called the Form factor (Horton, 1932). Smaller the values of „Rfe more elongated will be the basin/watershed. The values of Form factor in the study area ranges from 0.19 to 5.85. The sub-watersheds are more or less elongated in shape indicating lower peak flow for longer duration.

\section{Circularity Ratio (Rc)}

The circularity ratio 'Rc' is a shape measured depending on stream flow in the sub basin (Miller, 1953). The circularity ratio is influenced by the length and frequency of stream, geological structures, land use/land cover, climate, relief and slope of the basin. The 'Rc' values for the sub-watersheds varies from 0.27 to 0.42 indicating that all the sub-watersheds are of less circular in shape, low to moderate relief. 


\section{International Journal of Science and Research (IJSR) \\ ISSN (Online): 2319-7064}

Index Copernicus Value (2013): 6.14 | Impact Factor (2014): 5.611

Table 2: Morphometric Parameters Calculation

\begin{tabular}{|c|c|c|c|c|c|c|c|c|c|c|c|c|}
\hline Sub & Area & Perimeter & \multicolumn{4}{|c|}{ Linear Parameter } & \multicolumn{4}{|c|}{ Shape Parameter } \\
\cline { 6 - 13 } & $(\mathrm{Km} 2)$ & $(\mathrm{Km})$ & $R m$ & $D d$ & $F s$ & $R t$ & $L g$ & $R f$ & $R c$ & $R e$ & $C c$ & $B s$ \\
\hline $\begin{array}{c}\text { Patershed } \\
\begin{array}{c}\text { Parttikattupudur } \\
\text { (SW1) }\end{array}\end{array}$ & 53.471 & 45.229 & 7.49 & 1.254 & 1.664 & 1.968 & 0.398 & 0.442 & 0.328 & 0.375 & 1.745 & 2.262 \\
\hline $\begin{array}{c}\text { Ayyampalaiyam } \\
\text { (SW2) }\end{array}$ & 102.20 & 60.413 & 4.219 & 1.422 & 1.829 & 3.095 & 0.351 & 0.584 & 0.352 & 0.431 & 1.686 & 1.712 \\
\hline $\begin{array}{c}\text { Sedapalaiyum } \\
\text { (SW3) }\end{array}$ & 86.692 & 63.486 & 3.162 & 1.56 & 2.00 & 2.646 & 0.32 & 5.852 & 0.27 & 1.365 & 1.923 & 0.171 \\
\hline $\begin{array}{c}\text { Irugur } \\
\text { (SW4) }\end{array}$ & 39.618 & 34.155 & 4.38 & 2.058 & 2.726 & 7.646 & 0.243 & 0.198 & 0.426 & 0.251 & 1.531 & 5.05 \\
\hline $\begin{array}{c}\text { Kollampalaiyum } \\
\text { (SW5) }\end{array}$ & 40.256 & 42.994 & 3.056 & 1.942 & 2.409 & 2.256 & 0.257 & 1.255 & 0.273 & 0.632 & 1.911 & 0.797 \\
\hline Tennamanallur (SW6) & 31.412 & 32.117 & 2.704 & 1.88 & 2.483 & 2.429 & 0.265 & 3.178 & 0.382 & 1.007 & 1.616 & 0.314 \\
\hline
\end{tabular}

\section{Elongation Ratio (Re)}

It is the ratio between the diameter of the circle of the same area as the drainage basin and the maximum length of the basin. A circular basin is more efficient in run -off discharge than an elongated basin (Singh, 1967). The value of elongation ratio $(\mathrm{Re})$ generally varies from 0.6 to 1.0 associated with a wide variety of climate and geology. Values close to 1.0 are typical of regions of very low relief, whereas that of 0.6 to 0.8 are associated with high relief and steep ground slope (Strahler, 1964). 'Re' values in the present sub-watersheds varies from 0.25 to 1.36.The subwatersheds SW6 (1.00), and SW3 (1.36) have higher 'Re' value indicating high infiltration rate, low runoff, circular basin and rest of the sub-watersheds are less elongated.

\section{Basin Shape}

Basin shape shows the geometry of the basin. The ideal shape of the basin is frequently disturbed by geological, lithological and relief factors. Three indices namely form factor, elongation ratio have been computed to understand the basin shape. In the present study the basin factor ranges from 0.17-5.05. The SW1 and SW4 have low flood discharge period and other sub watershed have high discharge period.

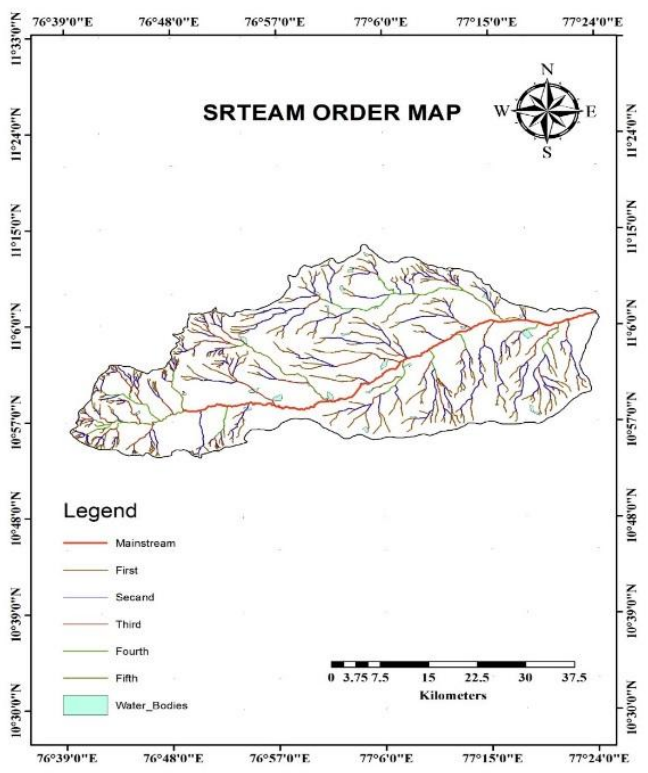

Figure 4: Drainage Order Map

\section{Compactness Co efficient (Cc)}

Compactness Coefficient (Cc) is used to express the relationship of a hydrologic basin to that of a circular basin having the same area as the hydrologic basin. A circular basin is the most susceptible from a drainage point of view because it will yield shortest time of concentration before peak flow occurs in the basin (Nooka Ratnam et al. 2005). The value of the study are varies from 1.53 (SW4) to 1.92(SW3). The values indicates there wide variation in the watershed.

\section{Generation of Thematic Maps}

Thematic maps like landuse/landcover, lineament, geomorphology map were generated using LISS IV data. Drainage map was extracted from the toposheet. The soil map was obtaind from National Bureau of Soil Survey toposheet and geology map was obtained from Geological Survey of India toposheet. The slope map was obtained from SRTM data.

\section{Land Use / Land Cover}

The land use /land cover analysis is the important phenomena which deals with the great emphasis of past and present. The land cover features are identified from the satelite data IRS P6(LISS IV). The land cover features identified in the study area are crop land, plantation, fallow land, river, waterbodies, barren rocky, cultivable land, open scrub, scrub forest, rural built up, urban builtup, scrub forest and current shifting cultivation. The land use land cover map is shown in Figure 5 .

\section{Slope}

The slope of any terrain is one of the factors controlling the infiltration of groundwater into the sub-surface and also a suitability indicator from the groundwater prospect point of view. Higher slope area facilitates high run-off allowing less residence time for surfacewater, whereas in the gentle slope area the surface run-off is slow, allowing more time for surfacewater to percolate and hence comparatively more infiltration. The slope map of the study area is shown in Figure 6. In our present study, the slope ranges between mild and moderate slope has been considered for prioritization. 


\section{International Journal of Science and Research (IJSR) \\ ISSN (Online): 2319-7064}

Index Copernicus Value (2013): 6.14 | Impact Factor (2014): 5.611

Soil

Soil plays a major role in groundwater recharge and meets the basic needs of all agricultural production. The soil types exist in the study area are clayey loamy soil, clayey soil, red loamy soil, gravely clayey soil and rocky outcrops. The soil map is shown in Figure 7. From observationthe gravely cayey soil favours higher recharge and clayey soil has lower water recharge capability.

\section{Lineament and Lineament Density}

Lineaments are straight linear elements visible at the Earth's surface as a significant "lines of landscape" (Hobbs, 1904). These are primarily a reflection of discontinuities on the Earth 's surface caused by geological or geomorphic processes (Clark \& Wilson, 1994). Geological features that give rise to lineaments include faults, shear zones, fractures, dykes and veins as well as bedding planes and stratigraphic contacts. Geomorphic features, which appear as lineaments on the maps, aerial photographs and satellite images include streams, linear valleys and ridgelines. The recharge will be higher in the higher lineament density region. The lineament map of the study area is shown in Figure 8.

\section{Drainage and Drainage Density Map}

A drainage basin is a natural unit draining runoff water to a common point. This map consists of water bodies, rivers, tributaries, perennial \& ephemeral streams, ponds. Drainage network helps in delineation of watersheds. Drainage density and type of drainage gives information related to runoff, infiltration relief and permeability. Dendritic drainage and homogenous rocks, indicate structural and lithological controls. The study area drainage is given in Figure 9.

\section{Geomorphology}

Geomorphology is the study of landforms of the earth, its description and genesis (Gupta, 2003). Geomorphology reflects various land form and structural features. The geomorphological map is shown in Figure 10. In our present study the geomorphological features are low dissected hills, flood plains, intermountane valley and anthropogenic origin. The flood plain regions have higher water recharge when compared to other features.

\section{Geology}

Geology plays an important role in the distribution and occurrence of groundwater. In the present study the geological features are extracted from the geological toposheet. The geology map of study area is shown in Figure 11. The present study consist of granite gneises and dolerite linings. Granite gneises favours higher recharge when compared to dolerite linings due to the higher fractured zones.
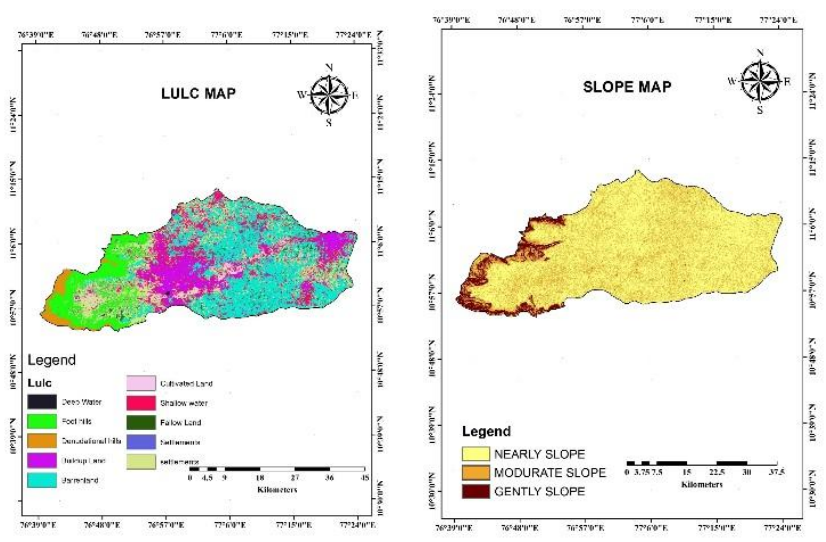

Figure 5: Land Use / Land Figure 6: Slope Map

\section{Cover Map}

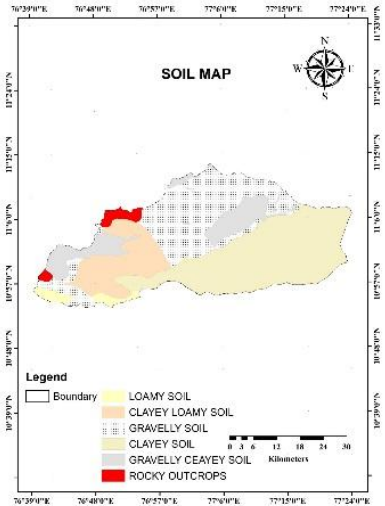

Figure 7: Soil Map

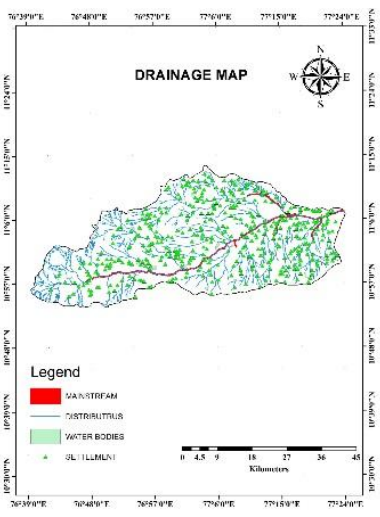

Figure 9 Drainage Map Map

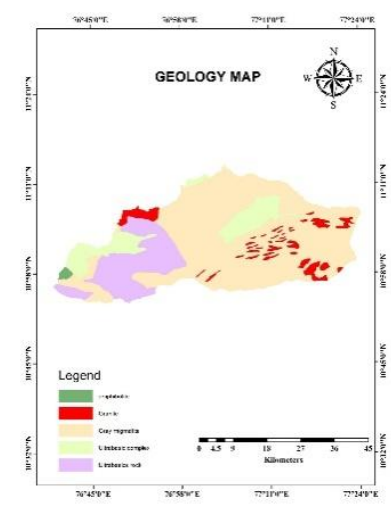

Figure 11: Geology Map

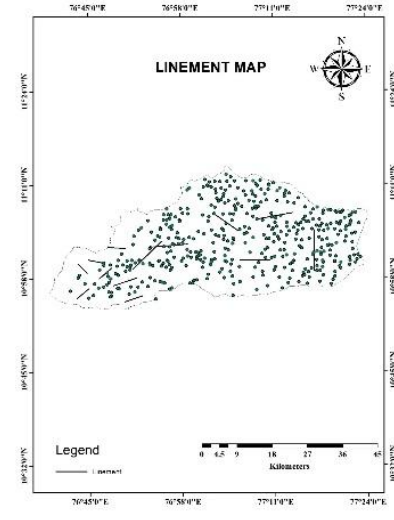

Figure 8: Lineament Map

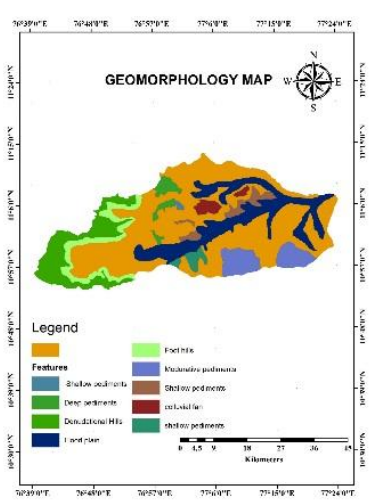

Figure 10: Geomorphology

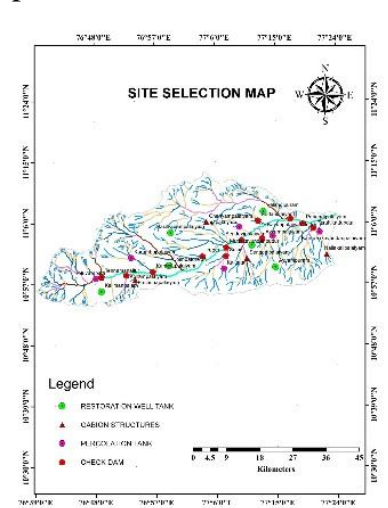

Figure 12: Location Map of 


\section{International Journal of Science and Research (IJSR) \\ ISSN (Online): 2319-7064}

Index Copernicus Value (2013): 6.14 | Impact Factor (2014): 5.611

Suitable Sites and Structures

\section{Selection of Suitable Site and Structure}

From our investigation the suitable site was identified from the integrated thematic map and by field visit. The recommended structures for the ground water recharge were Check dams, Percolation tank, Gabion structures and Restoration of well/pond in Coimbatore south Block. The location map of different sites and structures were shown in Figure 12.

\section{Conclusion}

Watershed prioritization is one of the most important aspects of planning for implementation of its development and management programs. The present study demonstrates the usefulness of GIS and Remote sensing for morphometric analysis and prioritization of the watersheds. The morphometric characteristics of different watersheds show their relative characteristics with respect to hydrologic response of the watershed. The suitable sites for identification of water recharge was analyzed using morphometric analysis and by integration of thematic maps. The various morphometric parameters analyzed are bifurcation ratio, stream frequency, drainage density, drainage texture, length of over land flow, form factor, elongation ratio, circulation ratio, basin shape, compactness coefficient. The thematic maps created from toposheets and satellite data. The thematic maps integrated are land use/land cover map, soil map, slope map, geology map, geomorphology map, drainage density map, lineament density map. The suitable sites and structures for the groundwater recharge was identified by integration of thematic maps and by the field visit. The structures proposed for recharge are six check dams, two percolation tank, three gabion structures and three ponds and wells are proposed for restoration work in Coimbatore South block. Check dams are proposed in Tennamanallur, Kollampalaiyam, Kumarapalaiyam, Irugur, Sulur, Muttukavundampudur, Sendevipalaiyam, Ayyampalaiyam, Sedapalaiyum, Kavuripalaiyampudur, Periandaipalayam, paruttikattupudua. Percolation tanks were proposed in Boluvampatti, Kurumbapaliyam, Kalangal, Pallipalaiyam, Karuppakavundampalaiyam, and Unjapalayam. Gabion structures were proposed in Pachchapalaiyam, Cheriyampalaiyam, Sengodipalaiyam, and Nallakalipalaiyam. Restoration works were proposed in Kalimangalam, Coimbatore JN, Saravanampalaiyam, Devarayampuram, Ayyampuram, and Velandipuram.

\section{References}

[1] Ajoy Das, Milan Mondal, Bhaskar Das, Asim Ratan Ghosh" Analysis of drainage morphometry and watershed prioritization in Bandu Watershed, Purulia, West Bengal through Remote Sensing and GIS technology - A case study" International Journal Of Geomatics And Geosciences Volume 2, No 4, 2012.

[2] Akramja Javed, Mohdyousuf Khanday \& Subahrais" Watershed prioritization using morphometric and land use/land cover parameters: a Remote sensing and GIS based approach" journal geological society of India v ol.78, July 2011.

[3] G. Ashenafi Tolessa \& P. Jagadeeswara Rao" Watershed development prioritization of Tandava river basin, Andhra Pradesh, India - gis approach" international journal of engineering science invention, volume 2, issue 2, February 2013.

[4] Balachandar.D, Alaguraja.P, Sundaraj.P, Rutharvelmurthy.K, Kumaraswamy.k" Application of Remote Sensing and GIS for Artificial Recharge Zone in Sivaganga District, Tamilnadu, India" International Journal Of Geomatics And Geosciences, Volume 1, No 1, 2010.

[5] Binay Kumar, Uday Kumar" Micro watershed characterization and prioritization using Geomatics technology for natural resources management" International Journal of Geomatics and Geosciences Volume 1, No 4, 2011.

[6] Biswas Arkoprovo, Jana Adarsa and Sharma ShashiPrakash" Delineation of Groundwater Potential Zones using Satellite Remote Sensing and Geographic Information System Techniques: A Case study from Ganjam district, Orissa, India" Research Journal of Recent Sciences ISSN 2277-2502, Vol. 1(9), 59-66, September (2012).

[7] Horton, R. E., 1945, Erosional development of streams and their drainage basins; Hydrological approach to quantitative morphology, Geological Society of American Bulletin, 56, pp. 275-370.

[8] T.A.Kanth \& Zahoorul Hassan" Morphometric analysis and prioritization of watersheds for soil and water resource management in Wular catchment using geo-spatial tools" international journal of geology, earth and environmental sciences, 2012 vol. 2 (1) January-April.

[9] Lakshmamma, Nagaraju .D, Mahadevaswamy.G, Siddalingamurthy.S, Manjunatha.S" Morphometric analysis of Gundal watershed, Gundlupettaluk, Chamarajanagar district, Karnataka, India" International Journal of Geomatics and Geosciences Volume 1, No 4, 2011.

[10] Manjunath H. N \& Suresh T. S" Morphometric and land use / land cover based sub watershed prioritization of Torehalla using remote sensing and gis" international journal of applied and natural sciences (ijans)issn(p): 2319-4014; issn (e): 2319-4022 vol. 3, issue 1, jan 2014.

[11] Miller, V. C., 1953. A quantitative geomorphic study of drainage basin characteristics in Clinch Mountain area, Virginia and Tennessee Project. NR 389-042, Tech. Report 3, Dept. of Geol. Columbia University.

[12] Nooka Ratnam, K., Srivastava, Y.K., Venkateswara Rao, V., Amminedu, E. And Murthy, K.S.R (2005).Check dam positioning by Prioritization of Microwatersheds using SYI model and Morphometric Analysis and Remote Sensing and GIS Perspective. Indian Soc. Rem. Sen., 33(1): 25-38.

[13] Patel Ajay, Khalid Mahmood, Singh Vijay, Thakkar Paru P, Jose Joy, Patel Nayan and Kalubarme, M.H. "Morph metric and Land use Analysis for Watershed Prioritization in Gujarat State, India” International Journal of Scientific \& Engineering Research, Volume 5, Issue 2, February-2014.

[14] Radhakrishnan .D, Ramamoorthy .P" Delineation of Groundwater Recharge Potential zones in Mailam Block, Villupuram district, Using GIS" International Journal of Water Research 2014; 2(2): 71-75.

[15] Sachin Panhalkar \& C. T.Pawar" Watershed development prioritization by applying werm model and gis techniques in vedganga basin (India)" arpn journal of agricultural and biological science, vol.6, no.10, October 2011 